\title{
Pengaruh Likuiditas, Profitabilitas, Solvabilitas, dan Ukuran Perusahaan Terhadap Audit Delay pada Perusahaan Jasa Sub Sektor Transportasi yang Terdaftar di Bursa Efek Indonesia Periode 2014-2018
}

\author{
Erita \\ eritasyofyan4516@gmail.com \\ STKIP PGRI Sumatera Barat
}

\begin{abstract}
Abstrak
Hasil penelitian ini menunjukan bahwa: (1) Likuiditas tidak berdampak signifikan terhadap audit delay. Koefisien regresi variabel Likuiditas $\left(X_{1}\right)$ sebesar 0,0566 yang bertanda

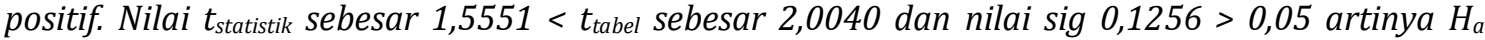
ditolak dan $\mathrm{H}_{0}$ diterima. (2) Profitabilitas tidak berdampak signifikan terhadap audit delay. Koefesien regresi variabel profitabilitas $\left(X_{2}\right)$ sebesar 0,0258 yang bertanda positif. Nilai $t_{\text {statistik }}$ sebesar 1,3016 $<t_{\text {tabel }} 2,0040$ dan nilai sig 0,1985 $>0,05$ artinya $H_{a}$ ditolak dan $H_{0}$ diterima. (3) Solvabilitas berdampak signifikan terhadap audit delay. Koefesien regresi variabel solvabilitas $\left(X_{3}\right)$ sebesar 0,1394 yang bertandaa positif. Nilai $t_{\text {statistik }} 2,2764<t_{\text {tabel }} 2,0040$ dan nilai sig 0,0267 $<0,05$ artinya $H_{a}$ diterima dan $H_{0}$ ditolak. (4) Ukuran Perusahaan tidak berdampak signifikan terhadap audit delay. Koefesien regresi variabel ukuran perusahaan $\left(X_{4}\right)$ 0,0084 yang bertanda positif. Nilai $t_{\text {statistik }} 1,12208<t_{\text {tabel }} 2,0040$ dan nilai sig 0,2667 $>0,05$ artinya $H_{a}$ ditolak dan $H_{0}$ diterima. (5) Likuiditas, Profitabilitas, Solvabilitas, Ukuran Perusahaan secara simultan berdampak signifikan terhadap audit delay pada perusahaan Jasa yang terdaftar di Bursa Efek Indonesia tahun 20142018. Berdasarkan yang diperoleh adalah nilai $F_{\text {statistik }}$ sebesar 2,7417 dan $F_{\text {tabel }} 2,54$. Dengan demikian hasil yang diperoleh $F_{\text {statistik}} 2,7417>F_{\text {tabel }} 2,54$ dan nilai sig 0,0337 $<0,05$ maka keputusannya Ha diterima dan $H_{0}$ ditolak.
\end{abstract}

Kata kunci : audit delay, likuiditas, profitabilitas, solvabilitas, ukuran perusahaan

\section{Pendahuluan}

Laporan keuangan merupakan hal yang penting bagi investor untuk menilai kinerja dan tanggung jawab manajemen perusahaan. Laporan keuangan adalah laporan yang menunjukan kondisi keuangan perusahaan pada saat ini atau pada suatu priode tertentu.

Manfaat laporan keuangan akan berkurang apabila laporan tersebut tidak disajikan pada tepat waktu. Menurut Palmon dalam(Apriyani, 2015:169), informasi yang diperlakukan oleh pihak-pihak yang berkepentingan dapat bermanfaat bilamana disajikan secara akurat dan tepat pada saat dibutuhkan oleh pemakai laporan keuangan, namun informasi tidak lagi disajikan secara akurat dan tepat waktu.

Kantor Akuntan Publik (KAP) yang independen objektif dan memiliki keahlian dalam sangat diperlukan dalam melakukan audit laporan keuangan perusahaan publik. Peran KAP ini menjadi sangat penting, dimana laporan auditnya akan menjadi pengesahan akan kebenaran kinerja perusahaan yang tergambar di laporan keuangan perusahaan publik. KAP akan mengeluarkan pendapat atas kewajaran laporan keuangan perusahaan yang telah diaudit.

Bapepam-LK mengeluarkan Surat Keputusan Ketua Bapepam Nomor: KEP-36/PM/2003 yang menyatakan bahwa laporan keuangan disertai dengan laporan akuntan dengan pendapat yang lazim untuk disampaikan kepada Bapepam ISSN: 2302-8556 E-Jurnal Akuntansi Universitas Udayana 8.2 (2014): 283-299 285 selambat-lambatnya pada akhir bulan ketiga setelah tanggal laporan keuangan tahunan. Di Bursa Efek Indonesia, masih terdapat perusahaanperusahaan yang terlambat menyerahkan laporan keuangannya. Hal ini sebagian besar disebabkan oleh lamanya waktu penyelesaian audit. 


\section{Tinjauan Pustaka}

\subsection{Audit Delay}

Menurut Aryati dan Theresia dalam (Pramesti, 2012) menjelaskan bahwa audit delay adalah rentang waktu penyelesaian pelaksanaan audit laporan keuangan tahunan, yang diukur berdasarkan lamanya waktu atau hari yang dibutuhkan untuk memperoleh laporan auditor independen atas audit laporan keuangan tahunan perusahaan, sejak tanggal tutup tahun buku perusahaan yaitu 31 Desember sampai tanggal yang tertera pada laporan auditor independen.

Menurut Subekti dalam (Arry Eksandy, 2017) bahwa "perbedaan waktu antara tanggal laporan keuangan dengan tanggal opini audit dalam laporan keuangan yang mengindikasikan tentang lamanya waktu penyelesaian audit yang dilakukan oleh auditor". Perbedaan inilah yang sering dinamai dengan audit delay.

\section{2. $\quad$ Likuiditas}

Menurut Irham Fahmi (2012:87) Likuiditas merupakan gambaran suatu kemampuan suatu perusahaan dalam memenuhi kewajiban pendeknya secara lancar dan tepat waktu sehingga likuiditas sering disebut short term liquidity.

Likuiditas menunjukkan kemampuan perusahaan untuk membayar kewajiban finansial jangka pendek tepat pada waktunya, Sartono dalam (Gina, Budiartha, 2017:1083)

\subsection{Profitabilitas}

Menurut Givoly dan Palmon dalam (Brawida Uthama, 2016:365) perusahaan yang memiliki profitabilitas baik akan cenderung ingin mempublikasikan laporan keuangan auditannya lebih cepat agar dapat memberi sinyal positif untuk para penggunanya dalam mengambil keputusan.

Tingkat Profitabilitas, variabel ini diukur dengan ROA (Return On Asset). "ROA merupakan proporsi antara laba bersih dengan total asset yang terdapat pada laporan keuangan tahunan masing-masing emiten" (Pramesti, 2012:22).

\subsection{Solvabilitas}

Menurut Saemargani (2015), Solvabilitas Perusahaan mempunyai pengaruh signifikan terhadap audit delay, Solvabilitas adalah kemampuan perusahaan untuk memenuhi kewajiban perusahaan meliputi utang jangka pendek dan jangaka panjang , baik perusahaan masih berjalan maupun dalam keadaan dilikuidasi (Sunyoto, 2013:101)

\subsection{Ukuran Perusahaan}

Ukuran Perusahaan adalah besar kecilnya suatu perusahaan yang dilihat dari besarnya aset yang dimiliki oleh perusahaan tersebut. Menurut (Saemargani, 2015:2).

\subsection{Keterkaitan Variabel}

\subsubsection{Pengaruh Likuiditas terhadap Audit Delay}

Likuiditas merupakan kemampuan perusahaan dalam membayar kewajiban-kewajiban jangka pendeknya dengan menggunakan aset lancar yang dimiliki. perusahaan yang dimiliki tingkat likuiditas yang tinggi maupun perusahaan dengan tingkat likuiditas yang rendah mencapaikan laporan keuangan secara tepat waktu dengan tujuan agar pihak keditor dapat mengetahui kemampuan perusahaan dalam membayar pinjaman yang diberikan pihak kreditor terhadap perusahaan.

$\mathbf{H}_{\mathbf{1}}$ : Likuiditas tidak Berdamapak Signifikan terhadap Audit Delay Pada Perusahaan jasa sub sektor transportasi yang Terdaftar di Bursa Efek Indonesia Periode 2014-2018

\subsubsection{Pengaruh Profitabilitas terhadap Audit Delay}

Perusahaan yang memiliki tingkat profitabilitas yang tinggi membutuhkan waktu audit lebih cepat karena adanya pertanggungjawaban untuk menyampaikan kabar baik kepada publik. Perusahaan akan mengulur waktu untuk publikasi laporan keuangan dikarenakan perusahaan menghindari adanya bad news karena terjadi profit yang rendah. Perusahaan tidak akan 
menunda penyampaian informasi yang berisi berita baik (good news), maka perusahaan yang mampu menghasilkan profit akan cenderung mengalami audit delay yang lebih pendek, sehingga hal tersebut dapat segera disampaikan kepada para investor dan pihak-pihak yang berkepentingan lainnya.

$\mathbf{H}_{2}$ : Profitabilitas tidak Berdamapak Signifikan terhadap Audit Delay Pada Perusahaan jasa sub sektor transportasi yang Terdaftar di Bursa Efek Indonesia periode20142018

\subsubsection{Pengaruh Solvabilitas terhadap Audit Delay}

Solvabilitas merupakan kemampuan suatu perusahaan dalam memenuhi kewajiban jangka panjangnya. Solvabilitas suatu perusahaan diukur dengan membandingkan jumlah utang dengan jumlah aktiva. Dimana proporsi hutang yang besar terhadap total aktiva akan meningkatkan kehati-hatian auditor terhadap laporan keuangan yang akan diauditnya, sehingga dalam penyelesaian audit laporan keuangan perusahaan tersebut dapat mengalami keterlambatan. Hal ini disebabkan semakin tinggi tingkat hutang akan meningkatkan risiko keuangan perusahaan. Perusahaan dengan utang yang tinggi akan berusaha menutupi utang mereka agar tidak diketahui stockholder sehingga mengakibatkan keterlambatan dalam mempublikasikan laporan keuangannya.

$\mathbf{H}_{3}$ : Solvabilita Berdamapak Signifikan terhadap Audit Delay Pada Perusahaan jasa sub sektor transportasi yang Terdaftar di Bursa Efek Indonesia periode2014-2018

\subsubsection{Pengaruh Ukuran Perusahaan terhadap Audit Delay}

Ukuran Perusahaan merupakan ukuran atau besarnya asset yang dimiliki oleh perusahaan. Keadaan yang dikehendaki oleh perusahaan adalah perolehan laba bersih sesudah pajak karena bersifat menambah modal sendiri. Perusahaan yang berukuran lebih besar cenderung memiliki public demand akan informasi yang lebih tinggi dibanding dengan perusahaan yang lebih kecil. Public demand akan informasi yang tinggi terhadap perusahaan memungkinkan tumbuhnya kepercayaan akan produk yang dihasilkan oleh perusahaan tersebut. Kepercayaan tersebut dapat meningkatkan tingkat keberlangsungan usaha dari perusahaan tersebut. "Semakin bagus ukuran perusahaan akan diproksikan dengan semakin tinggi total asset yang dimiliki oleh suatu entitas, akan semakin besar kemungkinan perusahaan untuk menggunakan jasa KAP the big four".

$\mathbf{H}_{4}$ : Ukuran Perusahaan Tidak Berdampak Signifikan terhadap Audit Delay Pada Perusahaan Jasa sub sektor Transportasi yang Terdaftar di Bursa Efek Indonesia Periode2014-2018

\section{Kerangka Konseptual}

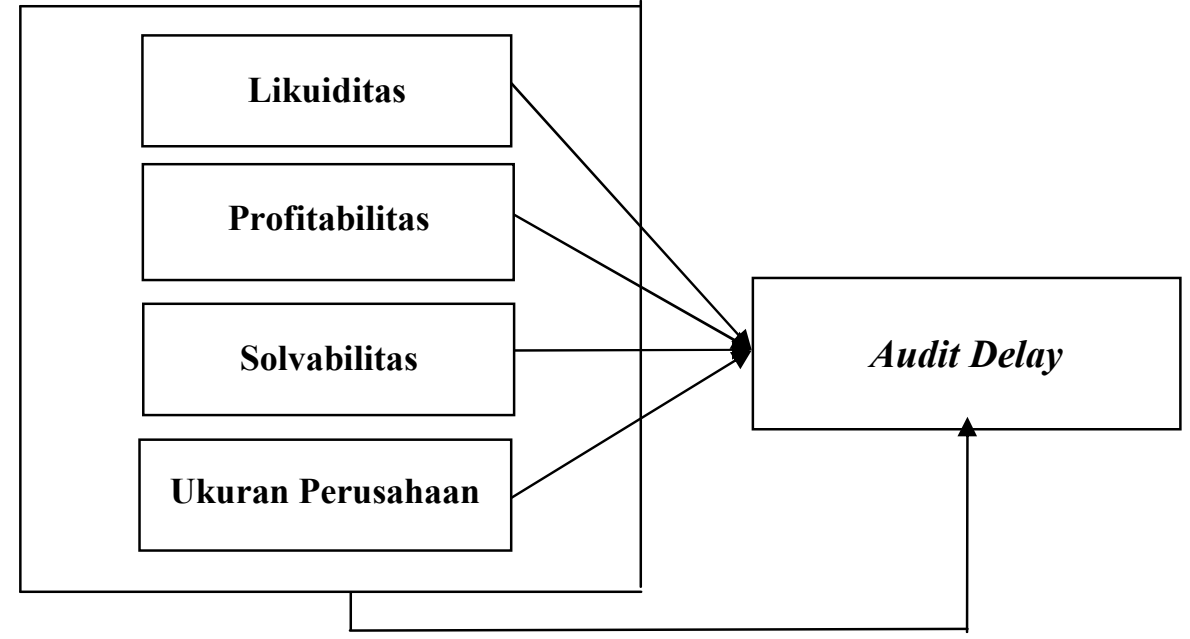

Gambar 1. Kerangka Konseptual 


\section{Metodelogi Penelitian}

\subsection{Populasi dan Sampel}

Pada penelitian ini yang menjadi populasi adalah seluruh perusahaan jasa sub sektor transportasi yang terdaftar di Bursa Efek Indonesia sebanyak 31 perusahaan periode 20142018. Sedangakan perusahaan yang menjadi sampel yaitu sebanyak 12 perusahaan dengan tahun penelitian sebanyak 5 tahun (2014-2018).

\subsection{Defenisi Operasional}

Pada penelitian ini terdapat variabel dependen yaitu Audit Delay dan variabel independen yaitu likuiditas, profitabilitas, solvabilitas, dan ukuran perusahaan.

\subsubsection{Audit Delay}

Audit Delay adalah selisih waktu antara berakhirnya tahun fiskal sampai dengan tanggal diselesaikannya laporan audit. Menurut (Arry Eksandy, 2017)audit delay diukur dengan menggunakan auditor's signature lag dengan satuan hari, seperti rumus dibawah ini:

Audit Delay = Tanggal Tahun Tutup Buku - Laporan Audit Ditandatangangi Oleh Auditor

\subsubsection{Likuiditas}

Likuiditas merupakan kemampuan perusahaan dalam membayar kewajiban-kewajiban jangka pendeknya dengan menggunakan aset lancar yang dimiliki. Likuiditas diukur dengan menggunakan Current Ratio, menurut (Yunawati, 2016) Rasio ini dihitung dengan rumus sebagai berikut:

$$
\text { Current Ratio }=\frac{\text { Current Asset }}{\text { Current Liabilities }} \times 100 \%
$$

\subsubsection{Profitabilitas}

Proftabilitas adalah kemampuan perusahaan dalam menghasilkan laba yang diukur melalui rasio keuangan. Rasio profitabilitas yang digunakan untuk mengukur kemampuan perusahaan menghasilkan laba dan juga untuk mengetahui efektivitas perusahaan dalam mengelola sumber - sumber daya yang dimilikinya. Profitabilitas diukur berdasarkan Return on Asset (ROA) dengan satuan presentase (\%). Berikut rumus Return on Asset (ROA)

$$
R O A=\frac{\text { LabaBersi Ta un Berjalan }}{\text { Total Aktiva }} \times 100 \%
$$

\subsubsection{Solvabilitas}

Solvabilitas merupakan kemampuan suatu perusahaan untuk memenuhi seluruh kewajiban finansialnya pada saat perusahaan dilikuidasi. Solvabilitas diukur dengan Debt to Asset Ratio (DAR) dengan rumus sebagai berikut

$$
D A R=\frac{\text { Total Utang }}{\text { Total Aset }} \times 100 \%
$$

\subsubsection{Ukuran Perusahaan}

Ukuran perusahaan diartikan sebagai suatu skala yang diklasifikasikan besar kecil perusahaan dengan berbagai cara antara lain dinyatakan dalam total aset, nilai pasar saham, dan lain-lain. ukuranperusahaan diukur dengan satuan rupiah dengan rumus :

$$
\text { Ukuran Perusahaan }=L N \text { Total Aset }
$$




\section{Analisis Data dan Pembahasan}

\subsection{Analisis Data}

5.1.1. Analisis Deskriptif

Sesuai dengan hasil pengolahan datayang telah dilakukan diperolehringkasan hasil terlihat pada Tabel 1 dibawah ini:

Tabel 1. Hasil Statistik Deskriptif

\begin{tabular}{|l|c|c|c|c|c|}
\hline & $\mathrm{Y}$ & $\mathrm{X} 1$ & $\mathrm{X} 2$ & $\mathrm{X} 3$ & $\mathrm{X} 4$ \\
\hline Mean & 4.399742 & 4.342583 & 1.829862 & 3.840333 & 22.93850 \\
\hline Median & 4.445000 & 4.358500 & 1.945910 & 3.880000 & 21.54000 \\
\hline Maximum & 5.190000 & 6.399000 & 5.389072 & 6.090000 & 29.04000 \\
\hline Minimum & 3.760000 & 1.720000 & -1.609438 & 2.390000 & 18.03000 \\
\hline Std. Dev. & 0.256842 & 0.802428 & 1.282275 & 0.668532 & 3.936945 \\
\hline
\end{tabular}

Sesuai dengan proses deskriptif statistik yang telah dilakukan diketahui bahwarata-rata (mean) audit delayselama periode 5 tahun terakhir perusahaan jasa sub sektor transportasi yaitu 4,39 hari dan median audit delaynya yaitu 4,44 hari. Audit delaytertingginya (maximum) yaitu 5,19 hari, sedangkan audit delay terendahnya (minimum) yaitu 3,76 hari. Dengan rata-rata tingkat penyimpangan atau standar deviasinya yaitu 0,25.

Sesuai dengan proses deskriptif statistik yang telah dilakukan diketahui bahwarata-rata (mean) likuiditas selama periode 5 tahun terakhir perusahaan jasa sub sektor transportasi yaitu 4,34\% dan median likuiditas yaitu 4,35\%. likuiditastertingginya (maximum) yaitu 6,39\%, sedangkan likuiditasterendahnya (minimum) yaitu 1,72\%. Dengan rata-rata tingkat penyimpangan atau standar deviasinya yaitu 0,80.

Sesuai dengan proses deskriptif statistik yang telah dilakukan diketahui bahwarata-rata (mean) profitabilitas selama periode 5 tahun terakhir perusahaan jasa sub sektor transportasi yaitu 1,82\% dan median profitabilitas yaitu 1,94\%. profitabilitas tertingginya (maximum) yaitu $5,38 \%$, sedangkan profitabilitas terendahnya (minimum) yaitu $-1,60 \%$. Dengan rata-rata tingkat penyimpangan atau standar deviasinya yaitu 1,28.

Sesuai dengan proses deskriptif statistik yang telah dilakukan diketahui bahwarata-rata (mean) solvabilitas selama periode 5 tahun terakhir perusahaan jasa sub sektor transportasi yaitu 3,84\% dan median solvabilitas yaitu 3,88\%. solvabilitas tertingginya (maximum) yaitu 6,09\%, sedangkan solvabilitas terendahnya (minimum) yaitu 2,39\%. Dengan rata-rata tingkat penyimpangan atau standar deviasinya yaitu 0,66.

Sesuai dengan proses deskriptif statistik yang telah dilakukan diketahui bahwarata-rata (mean) ukuran perusahaan selama periode 5 tahu terakhir perusahaan jasa sub sektor transportasi yaitu 22,93 dan median ukuran perusahaan yaitu 21,54. Ukuran perusahaan tertingginya (maximum) yaitu 29,04, sedangkan ukuran perusahaan terendahnya (minimum) yaitu 18,03. Dengan rata-rata tingkat penyimpangan atau standar deviasinya yaitu 3,93.

\subsubsection{Hasil Uji Normalitas}

Berdasarkan hasil pengujian normalitas yang telah dilakukandenganmenggunakan uji Jargue Bera diperoleh ringkasan hasil terlihat pada Tabel 2 dibawah ini:

Tabel 2. Hasil Output Uji Normalitas

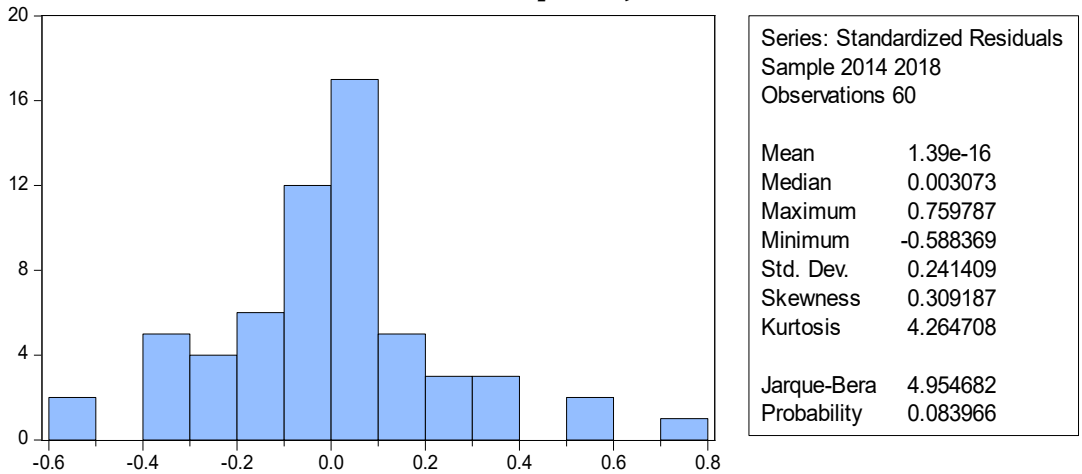


Pada tabel 2 diatas, diperoleh nilai statistik probability (JB) sebesar 4,954 dengan alpha 0,05 Jika nilai probability 0,083 > 0,05 dengan demikian dapat disimpulkan bahwa data dalam penelitian ini berdistribusi secara normal.

\subsubsection{Hasil Uji Chow}

Berdasarkan hasil pengujian chow test yang telah dilakukan maka diperoleh ringkasan hasil sebagai berikut:

\section{Tabel 3. Hasil Output Uji Chow-Test}

Redundant Fixed Effects Tests

Equation: Untitled

Test cross-section fixed effects

\begin{tabular}{|l|r|r|r|}
\hline \hline Effects Test & Statistic & d.f. & Prob. \\
\hline Cross-section F & 6.872847 & $(11,44)$ & 0.0000 \\
\hline Cross-section Chi-square & 59.998452 & 11 & 0.0000 \\
\hline \hline
\end{tabular}

Pada Tabel 3 di atas diperoleh nilai Fhitung adalah 6,872 dengan nilai Ftabel df $(11,44)$ dengan tingkat signifikan 5\% adalah 2,54. sehingga nilai Fhitung 6,872 > FTabel 2,54maka H0 diterima dan Ha ditolak, sehingga model data panel yang tepat digunakan adalah Fixed Effect Model.

\subsubsection{Hasil Uji Hausman}

Pengujian prasyarat kedua yaitu hausman test. Di dalam memastikan apakah model regresi data panel yang digunakan dengan random effect atau fixed effect. Maka dilakukan uji hausman test. Berdasarkan hasil pengujian hausman test yang telah dilakukan maka diperoleh ringkasan hasil sebagai berikut:

\section{Tabel 4. Hasil Output Uji Hausman}

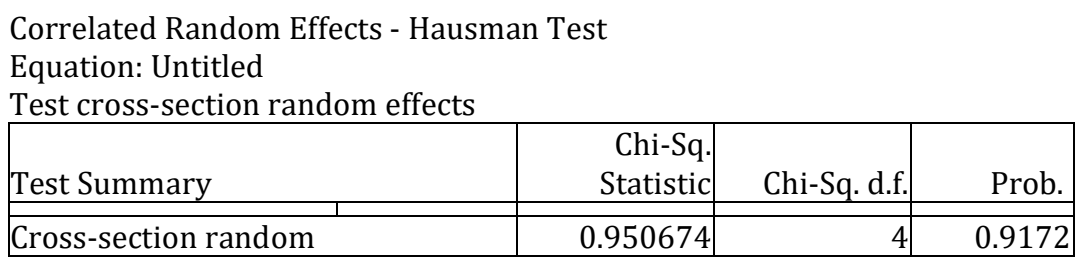

Berdasarkan tabel 4 di atas maka dapat dilihat nilai Chi-Squares (X2hitung) sebesar 0,950 dengan nilai Chi-Square (X2tabel) sebesar 9,48 sehingga nilai X2hitung 0,950<X2tabel 9,488 maka HO diterima HO ditolak, sehingga model yang tepat digunakan untuk regresi data panel yaitu Random Effect Model. 


\subsubsection{Uji LM}

Lagrange Multiplier (LM) adalah uji untuk mengetahui apakah model Random Effect atau model Common Effect yang lebih tepat. Hipotesis yang digunakan adalah Tabel 5. Hasil Output Uji LM

Lagrange multiplier (LM) test for panel data

Date: 02/13/20 Time: 20:02

Sample: 20142018

Total panel observations: 60

Probability in 0

\begin{tabular}{|l|c|c|c|}
\hline Null (no rand. effect) & Cross-section & Period & Both \\
\hline Alternative & One-sided & One-sided & \\
\hline \hline Breusch-Pagan & 32.47443 & 2.227904 & 34.70233 \\
\hline & $(0.0000)$ & $(0.1355)$ & $(0.0000)$ \\
\hline Honda & 5.698634 & -1.492617 & 2.974103 \\
\hline & $(0.0000)$ & $(0.9322)$ & $(0.0015)$ \\
\hline King-Wu & 5.698634 & -1.492617 & 1.664561 \\
\hline & $(0.0000)$ & $(0.9322)$ & $(0.0480)$ \\
\hline GHM & -- & -- & 32.47443 \\
\hline & -- & -- & $(0.0000)$ \\
\hline
\end{tabular}

Dari tabel 5 diatas diperoleh nilai Breusch-Pagan sebesar 34,702 dengan nilai ChiSquaretabel sebesar 11,07, sehingga nilai LMhitung > Chi-Squaretabel maka dapat disimpulkan bahwa Ha diterima dan model yang digunakan adalah random effect. Hasil ini sejalan dengan uji Hausman dan uji LM yang menyatakan bahwa uji random effect lebih baik dibandingkan dengan model yang lainya. 


\subsubsection{Pembentukan Model Regresi Panel}

Pembentukan model regresi data panel bertujuan untuk mengetahui arah dampak yang terbentuk antara variabel independen terhadap variabel dependen. Sesuai dengan pengujian data secara statistik maka dapat dibuat model regresi data panel yaitu Random Effect, karena model ini yang lebih baik dan tepat, seperti hasil pengujian dibawah ini:

Dependent Variable: $Y$

\section{Tabel 6. Hasil Output Random Effect}

Method: Panel EGLS (Cross-section random effects)

Date: 02/12/20 Time: 09:38

Sample: 20142018

Periods included: 5

Cross-sections included: 12

Total panel (balanced) observations: 60

Swamy and Arora estimator of component variances

\begin{tabular}{|c|c|c|c|c|}
\hline Variable & Coefficient & Std. Error & t-Statistic & Prob. \\
\hline $\mathrm{X} 1$ & 0.056685 & 0.036449 & 1.555182 & 0.1256 \\
\hline $\mathrm{X} 2$ & 0.025803 & 0.019823 & 1.301649 & 0.1985 \\
\hline $\mathrm{X} 3$ & 0.139419 & 0.061245 & 2.276410 & 0.0267 \\
\hline $\mathrm{X} 4$ & 0.008456 & 0.007536 & 1.122082 & 0.2667 \\
\hline $\mathrm{C}$ & 3.376985 & 0.358331 & 9.424198 & 0.0000 \\
\hline & \multicolumn{2}{|c|}{ Effects Specification } & & \\
\hline & & & S.D. & Rho \\
\hline \multicolumn{3}{|l|}{ Cross-section random } & 0.225738 & 0.6393 \\
\hline \multicolumn{3}{|l|}{ Idiosyncratic random } & 0.169556 & 0.3607 \\
\hline & Weighted & \begin{tabular}{|l|l} 
Statistics & \\
\end{tabular} & & \\
\hline R-squared & 0.166252 & \multicolumn{2}{|c|}{ Mean dependent var } & 1.400990 \\
\hline Adjusted R-squared & 0.105615 & \multicolumn{2}{|c|}{ S.D. dependent var } & 0.174246 \\
\hline S.E. of regression & 0.164788 & \multicolumn{2}{|c|}{ Sum squared resid } & 1.493534 \\
\hline F-statistic & 2.741785 & \multicolumn{2}{|c|}{ Durbin-Watson stat } & 2.078819 \\
\hline \multirow[t]{2}{*}{ Prob(F-statistic) } & 0.037538 & & & \\
\hline & \multicolumn{2}{|c|}{ Unweighted Statistics } & & \\
\hline R-squared & 0.099589 & \multicolumn{2}{|c|}{ Mean dependent var } & 4.399742 \\
\hline Sum squared resid & 3.504496 & \multicolumn{2}{|c|}{ Durbin-Watson stat } & 1.219635 \\
\hline
\end{tabular}

\subsection{Pembahasan}

\subsubsection{Pengaruh Likuiditas terhadap Audit Delay}

Berdasarkan hasil pengujian secara parsial diketahui likuiditas tidak berdampak signifikan terhadap audit delay pada perusahan jasa sub sektor transportasi. Pengujian hipotesis pertama menggunakan variabel likuiditas dengan nilai koefisien bertanda positif sebesar 0,056 dan diperoleh nilai tstatistik 1,555 < ttabel 2,004 dengan nilai probability 0,125. Dalam tahap pengujian ini digunakan tingkat kesalahan $5 \%(0,05)$. Hasil yang diperoleh menunjukan bahwa nilai probability $0,125>$ alpha 0,05 , maka keputusan Ha ditolak dan H0 diterima artinya likuiditas tidak berdampak signifikan terhadap audit delay.

Hasil penelitian ini sesuai yang dikemukakan menurut Munawir (2001) menyatakan bahwa "likuiditas itu menunjukkan kemmapuan suatu perusahaan untuk memenhi kewajiban atau hutang-hutangnya pada saat ditagih. Artinya bahwa likuiditas merupakan suatu kemampuan untuk memenuhi kebutuhan jangka pendeknya. Hasil penelitian ini di dukung oleh penelitian yang dilakukan oleh Chairani (2019) yang menyatakan bahwa likuiditas tidak berpengaruh signifikan terhadap audit delay.

Berdasarkan hasil penelitian, penulis dapat menyimpulkan bahwa rasio likuiditas tidak signifikan terhadap audit delay. Berarti kemampuan suatu perusahaan dalam memenuhi kewajiban jangka pendeknya yang mana tentu saja tidak berdampak terhadap audit delay karena nilai hutang yang tinggi. sehingga dapat dikatakan likuiditas tidak berdampak terhadap audit delay. 


\subsubsection{Pengaruh Profitabilitas terhadap Audit Delay}

Berdasarkan hasil pengujian secara parsial diketahui profitabilitas tidak berdampak signifikan terhadap audit delay pada perusahan jasa sub sektor transportasi. Pengujian hipotesis kedua menggunakan variabel profitabilitas dengan nilai koefisien bertanda positif sebesar 0,025 dan diperoleh nilai tstatistik 1,301 < ttabel 2,004 dengan nilai probability 0,198. Dalam tahap pengujian ini digunakan tingkat kesalahan $5 \%(0,05)$. Hasil yang diperoleh menunjukan bahwa nilai probability $0,198>$ alpha 0,05 , maka keputusam Ha ditolak dan H0 diterima artinya profitabilitas tidak berdampak signifikan terhadap Audit Delay.

Hasil penelitian ini sesuai dengan yang dikemukakan menurut Purnamasari (2012) menyatakan bahwa "Perusahaan yang memiliki tingkat profitabilitas yang tinggi membutuhkan waktu audit lebih cepat karena adanya pertanggungjawaban untuk menyampaikan kabar baik kepada publik".

Hasil penelitian ini di dukung oleh penelitian yang dilakukan oleh Brawida Uthama (2016) dengan judul "pergantian auditor sebagai pemoderasi pengaruh ukuran perusahaan, profitabilitasi, leverage pada audit delay". Berdasarkan hasil penelitian ini bahwa profitabilitas tidak berpengaruh signifikan terhadap audit delay.

Berdasarkan hasil penelitian, penulis dapat menyimpulkan bahwa rasio profitabilitas tidak berdampak signifikan terhadap audit delay. Karena tuntutan dari pihak-pihak yang berkepentingan tidak terlalu besar sehingga tidak memicu perusahaan untuk mempublikasikan laporan keuangan lebih cepat.

\subsubsection{Pengaruh Solvabilitas terhadap Audit Delay}

Berdasarkan hasil pengujian secara parsial diketahui solvabilitas berdampak signifikan terhadap audit delay pada perusahan jasa sub sektor transportasi. Pengujian hipotesis ketiga menggunakan variabel solvabilitas dengan nilai koefisien bertanda positif sebesar 0,139 dan diperoleh nilai tstatistik $2,276<$ ttabel 2,004 dengan nilai probability 0,026 . Dalam tahap pengujian ini digunakan tingkat kesalahan $5 \%(0,05)$. Hasil yang diperoleh menunjukan bahwa nilai probability 0,0267 > alpha 0,05, maka keputusam Ha diterima dan H0 ditolak artinya solvabilitas berdampak signifikan terhadap Audit Delay.

Hasil penelitian ini sesuai dengan yang dikemukakan menurut Heru Setiawan menyatakan bahwa "Tingkat besar kecilnya utang yang dimiliki perusahaan akan menyebabkan pemeriksaan dan pelaporan terhadap pemeriksaan utang perusahaan semakin lama sehingga dapat memperlambat proses audit oleh auditor".

Hasil penelitian ini di dukung oleh penelitian yang dilakukan oleh Nurahman Apriyana (2017) dengan judul "Pengaruh profitabilitas, solvabilitas, ukuran perusahaan, dan ukuran KAP terhadap Audit delay pada perusahaan properti dan real estate yang terdaftar di bursa efek indonesia periode 2013-2015". Berdasarkan hasil penelitian ini bahwa solvabilitas berpengaruh signifikan terhadap audit delay.

Berdasarkan hasil penelitian, penulis dapat menyimpulkan bahwa rasio solvabilitas berdampak pada audit delay. Berarti semakin tinggi solvabilitas maka audit delay cenderung semakin lama, sehingga solvabilitas mempengaruhi audit delay.

\subsubsection{Pengaruh Ukuran Perusahaan terhadap Audit Delay}

Berdasarkan hasil pengujian secara parsial diketahui ukuran perusahaan tidak berdampak signifikan terhadap audit delay pada perusahan jasa sub sektor transportasi. Pengujian hipotesis keempat menggunakan variabel ukuran perusahaan dengan nilai koefisien bertanda positif sebesar 0,008 dan diperoleh nilai tstatistik 1,122< ttabel 2,004dengan nilai probability 0,266. Dalam tahap pengujian ini digunakan tingkat kesalahan 5\% $(0,05)$. Hasil yang diperoleh menunjukan bahwa nilai probability 0,266 > alpha 0,05, maka keputusam Ha ditolak dan H0 diterima artinya ukuran perusahaan tidak berdampak signifikan terhadap auditt delay. 
Hasil penelitian ini sesuai dengan yang dikemukakan menurut Halim (2000) menyatakan bahwa "Semakin besar ukuran perusahaan yang diaudit maka audit delay akan semakin lama, ini berkaitan dengan semakin banyaknya sampel yang harus diambil dan semakin luas prosedur audit yang harus ditempuh".

Hasil penelitian ini di dukung oleh penelitian yang dilakukan oleh Fitria Ingga Saemargani (2015) dengan judul "Pengaruh ukuran perusahaan, umur perushaan, profitabilitas, solvabilitas, ukuran KAP, dan Opini Auditor terhadap audit delay". Berdasarkan hasil penelitian ini bahwa Ukuran perusahaan tidak berpengaruh signifikan terhadap audit delay.

Berdasarkan hasil penelitian, penulis dapat menyimpulkan bahwa rasio ukuran perusahaan tidak berdampak pada audit delay. Berarti besar atau kecilnya ukuran perusahan tidak mempengaruhi lamanya audit delay sehingga ukuran perusahaan tidak mempengaruhi audit delay.

\subsubsection{Pengaruh Likuiditas, Profitabilitas, Solvabilitas, dan Ukuran Perusahaan terhadap Audit Delay}

Berdasarkan pengujian hipotesis yang telah dilakukan diperoleh hasil likuiditas, profitabilitas, solvabilitas, dan ukuran perusahaan secara bersama-sama berdampak signifikan terhadap audit delay pada perusahaan jasa sub sektor transportasi. Hal ini dapat dilihat dengan perbandingan antara nilai Fstatistik sebesar 2,741 dan Ftabel sebesar 2,54.

Dapat dilihat bahwa diperoleh nilai Fstatistik sebesar 2,741 >Ftabel 2,54 dan nilai signifikan $0.037<0,05$. Hal ini bearti Ha diterima dan H0 ditolak. Dengan demikian dapat dikatakan bahwa likuiditas, profitabilitas, solvabilitas dan ukuran perusahaan secara bersamasama berdampak signifikan terhadap audit delay pada perusahaan jasa sub sektor transportasi.

Berdasarkan hasil analisis koefisien determinasi diperoleh hasil nilai R square sebesar 0,105 yang artinya 10,56\% merupakan dampak dari likuiditas, profitabilitas, solvabilitas dan ukuran perusahaan terhadap audit delay perusahaan jasa sub sektor transportasi. Sedangkan $89,44 \%$ merupakan dampak variabel lain yang diluar penelitian ini.

\section{Kesimpulan}

Berdasarkan hasil penelitian dan pembahasan di atas maka penelitian ini dapat disimpulkan bahwa:

1) Likuiditas tidak berdampak signifikan terhada audit delay pada perusahaan jasa sub sektor transportasi yang terdaftar di Bursa Efek Indonesia periode2014-2018.

2) Profitabilitas tidak berdampak signifikan terhadap audit delay pada perusahaan jasa sub sektor transportasi yang terdaftar di Bursa Efek Indonesia periode2014-2018.

3) Solvabilitas berdampak signifikan terhadap audit delay pada perusahaan jasa sub sektor transportasi yang terdaftar di Bursa Efek Indonesia periode 2014-2018.

4) Ukuran perusahaan tidak berdampak signifikan terhadap audit delay pada perusahaan jasa sub sektor transportasi yang terdaftar di Bursa Efek Indonesia periode 2014-2018.

5) likuiditas, Profitabilitas, solvabilitas, dan ukuran perasahaan secara simultan berdampak signifikan terhadap audit delay pada perusahaan jasa sub sektor transportasi yang terdaftar di Bursa Efek Indonesia periode 2014-2018. 


\section{Daftar Pustaka}

Ansofino, Jolianis, Yolamalinda, \& Harfilindo, H. (2016). Buku Ajar Ekometrika (1st ed.). Yogyakarta: Deepublish.

Apriyani. (2015). Pengaruh Solvabilitas, Opini Auditor, Ukuran Kap, Dan Komite Audit Terhadap Audit Delay. Jurnal Akuntansi Dan Sistem Teknologi Informasi, 11, 169-177.

Arikunto. (2010). Prosedur Penelitian Suatu Pendekatan Praktis, Edisi Revisi 2010,Cetakan Keempatbelas. Jakarta: Rineka Cipta.

Arikunto, S. (2013). Manajemen Penelitian. Jakarta: Rineka Cipta.

Arry Eksandy. (2017). Pengaruh Ukuran Perusahaan, Solvabilitas,Profitabilitas dan Komite audit Terhadap Audit Delay(Pada Perusahaan Properti dan Real Estate yang Terdaftar di Bursa Efek Indonesia Pada Tahun 2012-2015). Jurnal Akutansi Dan Keuangan ISSN 2549-791X, $1(2)$.

Ayu, I Gusti, D. (2015). Pengaruh Ukuran Perusahaan, Laba Operasi, Solvabilitas, Dan Komite Audit Pada Audit Delay. E-Jurnal Akuntansi Universitas Udayana ISSN: 2302-8556, 3(12), 481-495.

Brawida Uthama, J. (2016). Pergantian Auditor Sebagai Pemoderasi Pengaruh Ukuran Perusahaan, Profitabilitas, Leverage Pada Audit Delay. E-Jurnal Akuntansi Universitas Udayana ISSN: 2302-8556, 17(1), 364-394.

Budiartha, D. (2014). Pengaruh Total Aset, Tingkat Solvabilitas dan Opini Audit pada Audit Delay. E-Jurnal Akuntansi Universitas Udayana ISSN: 2302-8556, 3(7), 747-647.

Dian, P. (2014). Pengaruh Ukuran Perusahaan, Anak Perusahaan, Leverage Dan Ukuran Kap Terhadap Audit Delay. E-Jurnal Akuntansi Universitas Udayana ISSN: 2302-8556, 2(8), 283299.

Dura, J. (2017). Pengaruh Profitabilitas, Likuiditas, Solvabilitas dan Ukuran Perusahaan Terhadap Audit Report Lag Pada Perusahaan Yang Terdaftar di Bursa Efek Indonesia ( Studi Kasus Pada Sektor Manufaktur ). JIBEKA, 11(1), 64-70.

Fahmi. (2012). Analisis Kinerja Keuangan. Bandung: Alfabeta, cv.

Ghozali, I. (2011). Aplikasi Analisis Multivariate dengan Program SPSS. Semarang: Badan Penerbit UNDIP.

Gina, Budiartha, W. (2017). Pengaruh profitabilitas, Solvabilitas, Likuiditas, Ukuran Perusahaan dan Pergantian Manajemen Pada Audit Report Lag Perusahaan Perbankan. E-Jurnal Akuntansi Universitas Udayana ISSN: 2337-3067, 3(6), 1079-1108.

Indriantoro, Nur., B. S. (2009). Metodologi Penelitian Bisnis untuk Akuntansi dan Manajemen. Yogyakarta: BPFE Yogyakarta.

Irham Fahmi. (2012). Analisis Kinerja Keun.,yu... Bandung: Alfabeta.

Juliarsa. (2016). Pergantian Auditor Sebagai Pemoderasi Pengaruh Ukuran Perusahaan, Profitabilitas, Leverage Pada Audit Delay. E-Jurnal Akuntansi Universitas Udayana ISSN: 2302-8556, 17, 364-394. https://doi.org/2302-8556

Kasmir. (2010). Pengantar Manajemen Keuangan. Jakarta: Kencana Prenada Media Group.

Kasmir. (2011). Analisis Laporan Keuangan. Jakarta: Rajawali Pers.

Made Devi Miradhi dan Gede Juliarsa. (2016). Ukuran Perusahaan Sebagai Pemoderasi Pengaruh Profitabilitas Dan Opini Auditor Pada Audit Delay. E-Jurnal Akuntansi Universitas Udayana ISSN: 2302-8556, 16(1), 388-415.

Mahendra, W. (2014). Pengaruh Komisaris Independen, Kepemilikan Institusional, Profitabilitas, Likuiditas, dan Ukuran Prusahaan terhadap Ketepatanwaktuan. E-Jurnal Akuntansi Universitas Udayana ISSN: 2302-8556, 9(2), 304-324.

Marta ni, Dwi, dkk. (2018). Akuntansi Keuangan Menengah Berbasis PSAK Edisi 2 Buku 1. Jakarta Selatan: Salemba Empat.

Pramesti, H. (2012). Analisis Faktor-Faktor Audit Delay Perusahaan Manufaktur dan Finansial di Bursa Efek Indonesia. Jurnal Akuntansi Dan Sistem Teknologi Informasi, 9(1), 11-22.

Prasilya. (2015). Pengaruh Profitabilitas, Solvabilitas, Opini Auditor, Ukuran Perusahaan, Dan Reputasi Auditor Terhadap Audit Delay. Jurnal Ilmu Dan Riset Akuntansi, 4(9), 1-15. 
Saemargani, F. I. (2015). Pengaruh Ukuran Perusahaan, Umur Perusahaan, Profitabilitas, Solvabilitas, Ukuran KAP, dan Opini Auditor terhadap Audit Delay. Jurnal Nominal, 4(2).

Silvia Angruningrum, W. (2013). Pengaruh Profitabilitas, Leverage, Kompleksitas Operasi, Reputasi KAP dan Komite Audit pada Audit Delay. E-Jurnal Akuntansi Universitas Udayana ISSN: 2302-8556, 5(2), 251-270.

Sugiyono. (2014). Statistika untuk Penelitian. Bandung: Alfabeta.

Yunawati, S. (2016). Pengaruh Likuiditas Dan Solvabilitas Terhadap Profitabilitas pada Pt Industri Jamu dan Farmasi Sido Muncul Tbk. 2(2). 